DOI: https://doi.org/10.36910/6775-2524-0560-2021-44-07

УДК621.3.049

Павленко Вікторія Петрівна, науковий співробітник

https://orcid.org/0000-0003-2303-0993

Український науково-дослідний інститут спеціальної техніки та судових експертиз Служби безпеки України, м. Київ

\title{
ОСОБЛИВОСТІ МОНТАЖУ ТА СКЛАДАННЯ ДРУКОВАНИХ ПЛАТ
}

Павленко В. П. Особливості монтажу та складання друкованих плат. У статті було досліджено друковану плату, створену за допомогою багатошарових еластичних акрилових стрічок, щоб збільшити ресурс зносостійкості паяних з'єднань електронних пакетів шляхом послаблення вібрації в середовищі випадкових вібрацій. Визначено, що основним недоліком цієї концепції є іiі неможливість встановити електронні деталі на площі поверхні зовнішнього шару друкованої плати. Для ефективного просторового розміщення електроніки в цій роботі пропонується нова версія високодіючої друкованої плати 3 багатошаровими стрічками, посилена на тонкому металевому ребрі жорсткості, окремо від друкованої плати. Ця концепція забезпечує ефективне використання зони друкованої плати для монтажу електронних деталей, а також можливість послаблення вібрації.

Ключові слова: друкована плата; в’язка пластинка; термін використання; випадкова вібрація; послаблення вібрації.

Павленко В. П. Особенности монтажа и сборки печатных плат. В статье были исследованы високодействующую печатную плату (печатную плату), реализованную с помощью многослойных вязкоэластичных акриловых лент, чтобы увеличить ресурс износостойкости паяных соединений электронных пакетов путем ослабления вибрации в среде случайных вибраций. Определено, что основным недостатком этой концепции является ее невозможность установить электронные детали на площади поверхности внешнего слоя печатной платы. Для эффективного пространственного размещения электроники в этой работе предлагается новая версия печатной платы с многослойными вязкоупругих лентами, усиленная на тонком металлическом ребре жесткости, отдельноот печатной платы. Эта концепция обеспечивает эффективное использование зоны печатной платы для монтажа электронных деталей, а также возможность ослабления вибрации.

Ключевые слова: печатная плата; вязкая пластинка; срок использования; случайная вибрация; ослабление вибрации.

Pavlenko Viktoriia. Features of assembly of printed circuit boards. The article investigated a high-speed printed circuit board (printed circuit board), implemented using multilayer viscoelastic acrylic tapes, in order to increase the durability of the soldered joints of electronic packages by reducing vibration in an environment of random vibrations. It has been determined that the main disadvantage of this concept is its inability to mount electronic parts on the PCB surface area occupied by interlayers. For efficient spatial placement of electronics, this work proposes a new version of a high-end printed circuit board with multilayer viscoelastic tapes interlayered on a thin metal stiffener remote from the printed circuit board. This concept makes efficient use of the PCB area for mounting electronic parts, and also the ability to reduce vibration.

Keywords: Printed Circuit Board; viscous plate; term of use; random vibration; attenuation of vibration.

Постановка наукової проблеми. Випробування вільної вібрації проводиться при різних температурах, щоб отримати основні характеристики запропонованої друкованої плати. Ефективність друкованої плати може бути перевірена шляхом випробувань на випадкову вібраційну втому зразків друкованої плати із різною кількістю в'язкопружних шарів для порівняння терміну служби електронних пакетів.

В останні роки технологічні тенденції в різних галузях машинобудування, таких як автомобільна, оборонна, авіаційна та космічна техніка, швидко змінюються внаслідок промислової революції. Поява автономних перевезень, безпілотних літальних апаратів (безпілотних літальних апаратів) та великих сузір'їв невеликих супутників - кілька прикладів цих тенденцій, які змінюють комерційні та військові послуги [1-3]. Відповідно, ці останні тенденції зумовили прогрес у функціональних можливостях та продуктивності бортової електроніки для різних застосувань, де електроніка повинна бути компактнішою за обсягом і легшою за вагою.

У секторі електронного машинобудування зусилля зі зменшення маси та обсягу електроніки зосереджені переважно на розробці та використанні високоінтегрованих електронних пакетів [4]. Застосування цих пакетів дозволяє друкованій платі (друкованій платі) бути компактним за обсягом, оскільки вони забезпечують велику кількість входів/виходів та можливості обробки. Тим часом машинобудівний сектор зосередився на мінімізації масовості житлових конструкцій для інтеграції друкованої плати, оскільки корпус зазвичай займає більше $50 \%$ масового бюджету електроніки $[5,6]$. Тим не менш, конструкція корпусу повинна забезпечувати достатню міцність та жорсткість для запобігання виходу з ладу електроніки під час випробувань та періодів обслуговування.

Одним 3 основних механізмів відмови електроніки є втомний зрив паяльного з'єднання електронної упаковки внаслідок напруги, викликаної повторюваним відхиленням друкованої плати при вібраційному збудженні. 
Аналіз досліджень. У дослідженнях було запропоновано та вивчено кілька інших рішень, таких як недоповнення, укладання кутів та кутовий клей для збільшення терміну служби втомних паяних з'єднань [7-9]. Крім того, деякі дослідження зосереджувались на аналітичному підході для пошуку належного місця встановлення електронної упаковки на друкованій платі 3 точки зору мінімізації напруги припою [10].

Більш ефективний підхід до забезпечення терміну служби припою, порівняно з вищезгаданими методами [7-10], полягає у збільшенні здатності послаблення вібрації друкованої плати. До репрезентативних прикладів можна віднести застосування гумових кріплень, матеріалів для заливки, демпферів ударів частинок (PID) та активних регуляторів вібрації [11-14]. Серед них, PID привернули значну увагу до електроніки завдяки своїй простоті, невеликій вазі та ефективним характеристикам зменшення вібрації. PID є формою демпфера, який зазвичай складається 3 герметичної ємності, заповненої частинками, такими як металеві кульки. Амплітуду вібрації можна зменшити за рахунок кінетичної енергії, що генерується зіткненням частинок і тертям між частинками в контейнері. На сьогоднішній день було проведено кілька досліджень для дослідження різних типів PID $[13,15,16]$.

Виклад основного матеріалу й обгрунтування отриманих результатів. Друкована плата - це спеціальна пластина, на яку нанесено провідний малюнок, тобто електропровідні ланцюги електронної схеми. Даний малюнок розміщується на діелектрику, матеріалі, що володіє відносно поганою здатністю проводити струм.Найбільш затребуваними на сьогоднішній день $є$ двошарові друковані плати для електроніки. Їх головна особливість полягає в тому, що вони містять так званий провідний малюнок відразу 3 двох сторін.Малюнок на таких пристроях виконується 3 фольги. Друкована плата має спеціальні контактні майданчики і монтажні отвори, що дозволяє 3 легкістю виробляти монтаж необхідних компонентів.На двошарових або багатошарових платах існують також спеціальні отвори для забезпечення з'єднання електричного з'єднання між шарами. Розробка плат проводиться в спеціально призначених для цього програмах.

Існує уніфікована класифікація, яка $є$ загальноприйнятою для всіх держав. Відповідно до неї, друковані плати ділять залежно від кількості шарів з малюнком:

- односторонні плати, що володіють лише одним шаром провідного елемента, нанесеного на одну сторону діелектрика;

- двосторонні моделі плат, що володіють відразу двома шарами;

- багатошаровімоделі плат - це особливий вид, який виробляється шляхом нашарування декількох плат. У таких пристроях провідний елемент знаходиться не тільки на одній зі сторін, але також $\mathrm{i}$ всередині самої плати.

Для виготовлення пластин використовують високоякісні діелектрики. На сьогоднішній день, частіше за все, в виробництвах застосовують гетинакс або ж стеклотекстоліт. Варто зазначити, що плати також можуть бути як жорсткими, так і гнучкими.

Сучасний світ важко собі уявити без електроніки, яка в свою чергу ніяк не може існувати без якісних друкованих плат. Саме тому виготовлення друкованих плат має таку стратегічну важливість для всього світу.

Типові PID-індикатори (proportional integral derivative) вимагають щонайменше 20-30 мм простору для розміщення у напрямку поза площиною друкованої плати. Це може призвести до збільшення відстані між друкованими платами, що збільшує розміри структури корпусу електроніки. Інша потенційна проблема полягає в тому, що для послаблення реакцій друкованої плати в різних місцях монтажу електронних пакетів може знадобитися декілька кількох PID, якщо друкована плата неправильну або асиметричну конфігурацію.

Інший метод послаблення вібрацій, який називається демпфуванням обмеженого шару (CLD), також раніше досліджувались щодо електронних додатків [17,18]. Загалом, друкована плата, виготовлена за допомогою методу CLD, складається 3 декількох обмежених шарів, укріплених пластиною на поверхні друкованої плати. Ця форма є оптимальною для послаблення вібрацій за рахунок зниження тертя між шарами та пластинчастого матеріалу.

Однак навіть ця концепція має недолік з точки зору просторового розміщення електронних частин на друкованій платі, оскільки в'язка пластинка прикріплена до загальної поверхні друкованої плати, хоча деякі ділянки відкриті для забезпечення доступу до електронних частин. Для впровадження компактної та легкої електроніки необхідним завданням $є$ більш ефективне використання простору друкованої плати. У цьому дослідженні авторами запропоновано нову версію високодемпфірованої друкованої плати, щоб подолати недоліки попередньої концепції [19]. Запропонована нова версія друкованої плати має багато пластин, укріплених на тонкому металевому ребрі жорсткості окремо від 
друкованої плати. Це забезпечує ефективне використання зони друкованої плати для монтажу електронних частин, оскільки лише деякі частини механічної фіксації займають усю площу поверхні друкованої плати, на відміну від попередньої версії [19]. Для перевірки нової версії друкованої плати, представленої в аналізованому дослідженні, були проведені випробування на вільні вібрації при різних температурних умовах для отримання основних характеристик друкованої плати з в’язкою пластиною. Крім того, були виготовлені зразки друкованої плати з різною кількістю в’язких пластин, які піддавалися впливу середовища випадкових вібрацій для порівняння терміну служби електронних пакетів.

Динамічне відхилення друкованої плати під вібрацією обернено пропорційне квадрату власної частоти друкованої плати [7]. Тому типовий підхід до проектування для забезпечення терміну служби паяних з'єднань в електронних пристроях передбачає впровадження додаткових металевих ребержорсткості на друкованій платі $[20,21]$. Жорсткість також діє як провідний тепловий шлях для розсіювання тепла з друкованої плати до конструкції корпусу.

Однак вищезгаданий традиційний підхід до проектування, який зосереджений на збільшенні жорсткості плати, викликає збільшення маси та об'єму електроніки, оскільки конструкція корпусу стає об'ємною. Просторове розміщення різних електронних деталей (роз'ємів, паяльних кабелів тощо) на поверхні друкованої плати також стає менш ефективним, оскільки площа, що контактує з ребрами жорсткості, не може бути використана для монтажу цих деталей. Інше обмеження полягає в тому, що в деяких випадках термін використання електронних пакетів може не бути підвищений, навіть якщо збільшиться жорсткість плати. 3 цих причин підвищення здатності гасіння вібрацій друкованої плати за рахунок збільшення іï демпфіруючої здатності могло б бути набагато кращим рішенням, ніж традиційний підхід використання ребра жорсткості, якщо в електроніці немає проблеми теплового розсіювання

Щоб вирішити вищезгадану технічну проблему, окремими авторами [19] запропоновано використовувати високопоглинаючу друковану плату 3 багатошаровою в'язкою пластиною. Їх запропонована концепція складалася 3 друкованої плати FR-4, обмежених шарів, що складаються 3 того ж матеріалу друкованої плати, та в'язкоеластичних акрилових стрічок для прошарку обмеженихшарів на нижній стороні площини. Результати експериментальних випробувань показали, що високодіюча друкована плата 3 п'ятьма шарами жорсткості досягла коефіцієнта демпфірування 0,048, що в 3,67 рази вище, ніж у друкованої плати без шарів. Це призвело до зростання терміну служби більш ніж у 8,21 разів . Однак вищезгадана проблема, пов'язана 3 просторовим розміщенням електронних деталей на друкованій платі, ще не вирішена за допомогою цієї концепції, оскільки обмежені шари були безпосередньо прикріплені до нижньої поверхні плати.

У цьому дослідженні розглядається нова версія друкованої плати для подолання обмежень традиційної друкованої плати [19]. Нова версія складається 3 друкованої плати, обмежених шарів та двосторонніх стрічок з в'язкою пластиною. Друкована плата виготовлена 3 FR-4, іï розміри становлять 243 мм-60 мм-1,2 мм. Обмежені шари, зроблені з того ж матеріалу друкованої плати, були прикріплені до тонкого алюмінієвої ребра жорсткості за допомогою гнучкої пластинчастої стрічки. Можливість послаблення вібрацій запропонованої друкованої плати, в основному реалізувалася за рахунок розсіювання енергії, що виникає внаслідок деформації гнучких пластин.

Розмір ребра жорсткості з гнучкою пластинчастою стрічкою охоплює всю площу друкованої плати; це може ефективно послабити вібрацію, викликану не тільки першими глобальними режимами згинання, а й локальними режимами на більш високих частотах. Це забезпечує зменшення вібрації друкованих плат, що мають складну форму режиму, викликану неправильною та асиметричною конфігурацією плати. Ребро жорсткості має 15 механічних інтерфейсів для інтеграції ребра жорсткості на друкованій платі, що дозволяє віддалити його на 3 мм від друкованої плати. Ця конфігурація дозволяє використовувати площі поверхні з обох сторін друкованої плати для монтажу електронних частин. Це головна перевага, що відрізняе цю модель від попередньої версії [19]. Крім того, товщину друкованої плати, необхідну для задоволення вимог щодо жорсткості плати, можна було мінімізувати, оскільки вона була посилена тонким алюмінієвим ребрами жорсткості. При цьому процес демонтажу всього ребра жорсткості з обмеженими шарами можна легко виконати, якщо потрібна переробка деяких електронних деталей [19].

Виробничі системи зазвичай вимагають автоматизованих методів перевірки та випробування, щоб гарантувати якість. Доступні сьогодні методи, такі як MachineVision-MV, можна застосовувати у всіх виробничих процесах. Застосування комп'ютерного аналізу та інтерпретації зображень - це технологія, яка продемонструвала свій внесок у підвищенняпродуктивності та якості виробничих операцій практично у кожному промисловому сегменті [1]. В електронній промисловості МУвикористовується 
для перевірки друкованих плат на відстань між провідниками; друковані плати - для перевірки комплектації компонентів, свинцевих або контактних отворів після перевірки припою на його цілісність. Перевірка виконується не тільки як засіб сортування браку, але і для забезпечення зворотного зв'язку щодо продуктивності процесу [3]. Багато компаній із виробництва електронних друкованих плат використовують системи MVдля перевірки наявності та повноти пристроїв поверхневого монтажута компонентів друкованої плати.

Застосування технології MVпередбачає роботу з багатьма візуальними змінними. Навіть прості програми повинні оброблятизмінні. Освітлення та оптику у багатьох додатках можна оптимізувати для посилення контрасту, пов'язаного зі змінною, для якої купується система, або, навпаки, може допомогти зменшити вплив змінної на дані, необхідні для прийняття надійного рішення. В установці MVрекомендується спеціальне освітлення. У системі MVпроцес отримання зображення має вирішальне значення з функціональної точки зору. Внутрішні змінні процесу збору даних, такі як зміна яскравості, співвідношення сигнал/шум, впливають на загальну надійність системи. Хороший результат візуалізації вимагає менше обчислювальних ресурсів обробки зображення. Таким чином, зображення, отримане камерою, змінюється для одного і того ж продукту, що робить обробку зображення важливим кроком для усунення цього фактора. Велика частина цих змін в основному пов'язана з розсіюванням світла на варіаціях поверхні об'єкта (бруд або пил, наприклад).

Конкретна техніка освітлення залежить від геометричних властивостей об'єкта, фону та даних, які потрібно витягти 3 об'єкта. Освітлення області, що представляє інтерес, здійснюється лінійними світлодіодними масивами (інтенсивність контролюється струмом), де промені коливаються для поліпшення співвідношення спостережуваних об'єктів та зображення нижньої поверхні друкованої плати. Оскільки кожен роз'єм DIMM, що складається з 240 контактів, довгий (приблизно 140 мм в довжину) і вузький 10 мм в ширину, для отримання зображень 3 відповідною роздільною здатністю необхідно було зробити два зображення (ліворуч і праворуч) з кожного роз'єму DIMM для перевірки всі його 240 штифтів.

Проведення перевірки полягає у підрахунку кількості яскравих плям, які відповідають існуванню області, де в друковану плату були вставлені два роз'єми DIMM. Загальна площа, виділена цим роз'ємам на друкованій платі, приблизно вдвічі перевищує площу. Щоб знайти цю область, необхідно визначити положення центричної точки або розподіл фарбування. 3 цієї позиції обведено прямокутник, що обмежує мінімальну площу зображення, що підлягає огляду. Ця процедура усуває велику кількість паразитних шумів, викликаних відбиттями від інших областей зображення.

Після того, як штифти розташовані на заздалегідь визначеній відстані, можна підрахувати правильну кількість штифтів, підрахувавши кількість плям, і жодна різниця не пов'язана 3 дефектом, чи то погане розташування роз'єму, чи то зігнуті штифти. Система МУкерує за допомогою програмного забезпечення зображеннями у просторовій області. Іншими словами, процедури обробки зображень включають покращення зображення, вилучення функцій та аналіз/класифікацію зображення. Покращення зазвичай виконується для видалення небажаного шуму або вібрацій. Вилучення функцій передбачає сегментацію, структурування елементу, тощо.

Висновки та перспективи подальшого дослідження. У цій статті розглядається практика та результати останніх досліджень, результатом яких є нова версія високодіапазонної друкованої плати 3 гнучкими пластинами, спрямована на подолання недоліків 3 точки зору просторової ефективності електроніки. Для випробування на тривалість використання , зразки друкованої плати з різною кількістю прошарків $з$ гнучкої пластинчастої пластини були виготовлені та піддані дії вібраційного середовища до виходу з ладу електронних пристроїв. Результати випробувань показали, що запропонована концепція ефективно збільшила використання електронних пристроїв за рахунок зменшення динамічного відхилення друкованої плати під впливом випадкової вібрації. Напрямком подальших досліджень можуть стати напрями використання в електроніці високодіапазонних друкованих плат.

У статті також проведено аналіз останніх розробок та пілотних випробувань інноваційного автоматичного обладнання, призначеного для перевірки збірки компонентів зі штифтовими отворами, встановлених на друкованих платах. Проведений аналіз дозволив виявити критичні дефекти, що виникають під час складання компонентів на друкованих платах. Обладнання дозволяє отримувати зображення та здійснювати подальшу інтерпретацію для прийняття рішень.

References.

1. Raviteja, T.,Vedaraj I. An introduction of autonomous vehicles and a brief survey. J. Crit. Rev. -2020. - №7 - P. $196-202$. 
2. Boubeta-Puig J.,Moguel E., Sánchez-Figueroa F., Hernández J., Preciado J.C. An autonomous UAV architecture for remotesensing and intelligent decision-making. IEEE Internet Comput.-2018. -№22. - P. 6-15.

3. Curzi G.,Modenini D., Tortora P. Large constellations of small satellites: A survey of near future challenges and missions.Aerospace. -2020. -№7. 133p..

4. Yoon S.W., Petrov B., Liu K. Advanced wafer level technology: Enabling innovations in mobile, IoT and wearable electronics. InProceedings of the 2015 IEEE 17th Electronics Packaging and Technology Conference (EPTC), Singapore, 2-4 December. 2015. -P. 1-5.

5. Fenske M.T. The development of lightweight electronics enclosures for space applications. SAMPE J. -1999. -P. $25-34$.

6. García-Pérez A.,Ravanbakhsh A.,Sorribes-Palmer F., Alonso G. Structural shock verification by numerical analysis of the EPD payload units on board Solar Orbiter spacecraft. Acta Astronaut. -2020. -P. 282-292.

7. Xie D., Wu Z., Hai J., Economou M. Reliability enhancement of automotive electronic modules using various glues. InProceedings of the IEEE 68th Electronic Components and Technology Conference (ECTC), San Diego, CA, USA, 29 May-1 June. -2018. -P. 1-7.

8. Suhir E.,Ghaffarian R. Flip-Chip (FC) and Fine-Pitch-Ball-Grid-Array (FPBGA) underfills for application in aerospaceelectronics - Brief review. Aerospace. -2018. -P. 74.

9. Grieu M.,Massiot G., Maire O.,Chaillot A., Munier C., Bienvenu Y., Renard J. Durability modelling of a BGA componentunder random vibration. In Proceedings of the 9th International Conference on Thermal, Mechanical and Multiphysics Simulationand Experiments in Micro-Electronics and Micro-Systems (EuroSimE), Freiburg im Breisgau, Germany, 20-23 April. - 2008. -P. 1-8.

10. Lall P.,Pandurangan A.,Dornala K.,Suhling J., Deep J. Effect of shock angle on solder-joint reliability of potted assemblies under high-G shock. In Proceedings of the 19th IEEE Intersociety Conference on Thermal and Thermomechanical Phenomena in Electronic Systems (ITherm), Orlando, FL, USA, 21-23 July. - 2020. -P. 1-12.

11. Xiao W., Yu S., Liu L., Zhang F. Vibration reduction design of extension housing for printed circuit board based on particledamping materials. Appl. Acoust. -2020. -P. 1-16.

12. Yeo H.C., Guo N., Du H., Chen M. Active vibration control of the print circuit boards using piezoelectric bimorphs.Key Eng. Mater. -2007. -P. 1081-1084.

13. Veeramuthuvel P., Shankar K.,Sairajan K.K. Application of particle damper on electronic packages for spacecraft. Acta Astronaut. -2016.P. 260-270.

14. Vibration Attenuation PID Damper Part Numbers. Режим доступу: https://topline.tv/Vibration_Damping.html (дата звернення: 18.10.2021).

15. Zhou X.D.,Xiong C.W. Study on vibration and damping of printed circuit boards treated with partial constrained dampinglayer. Adv. Mater. Res. -2014. -P. 590-594.

16. Fang Z., Zheng L. Topology optimization for minimizing the resonant response of plates with constrained layer dampingtreatment. Shock. Vib. -2015. -P.376-385.

17. Park T.Y., Shin S.J., Park S.W., Kang S.J., Oh H.U. High-damping PCB implemented by multi-layered viscoelastic acrylic tapes for use of wedge lock applications. Eng. Fract. Mech. -2021.-241p.

18. STS-125 Mission Overview Priefing Paterials. https://www.nasa.gov/mission_pages/shuttle/shuttlemissions/(дата звернення: 18.10.2021).

19. Steinberg, D.S. Vibration Analysis for Electronic Equipment, 3rd ed.; John Wiley \& Sons Inc.: New York, NY, USA, 2000.

20. IPC-9701A. Performance Test Methods and Qualification Requirements for Surface Mount Solder Attachments; Association ConnectingElectronics Industries (IPC): Bannockburn, IL, USA. - 2006.

21. ECSS-E-HB-32-21A. Space Engineering: Adhesive Bonding Handbook; European Cooperation for Space Standardization (ECSS):Noordwijk, The Netherlands. -2011. 